13. Bulavin S.A. Non-waste energy saving technology for processing beet pulp / S.A. Bulavin, K.V. Kazakov, A.S. Kolesnikov // Sugar. - №3. - 2011. - P. 36-38.

14. Sugar beet processing products in feeding cattle. - Access mode: https://soft-agro.com/korovy/produkty-pererabotki-saxarnojsvekly-v-kormlenii-krs.html

15. Zelupukin Y.I. The expediency of processing of beet sugar production waste / Y.I. Zelupukin, S.Y. Zelupukin // Sugar. - №5. 2016. - P. 37-40.

16. Modern directions of use and utilization of beet pulp. - Access mode: http://diamantsugar.com.ua/ru/articles/sychasnnapryamki-vikoristannya-ta-ytilzats-byryakovogo-zhomy

Надійила 27.01.2018. До друку 08.02.2018

Адреса для переписки:

вул. Канатна, 112, м. Одеса, 65039

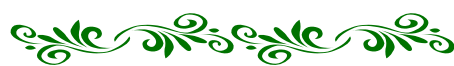

УДК [639.3.043:639.211]-021.4

LIUDMYLA FIHURSKA, PhD, Assistant Professor, Department of Feed and Biofuel Technologies Odessa National Academy of Food Technologies

\title{
TENDENCIES AND PECULIARITIES OF SHRIMP FEED PRODUCTION
}

\section{Abstrakt}

Aquaculture is food sector, which is growing rapidly in the last 25 years with annual growth rate 8,2\%. One of the most perspective branches of aquaculture is shrimp farming. The cost of feeds is up to $80 \%$ of the cost of shrimp breeding, so providing the industry with high-quality feeds is the important goal of the feed industry in all over the world. The theoretical research was devoted to the task of compound shrimp feed production. In order to satisfy shrimp requirements, shrimp feeding systems were shown. Existing shrimp breeding systems are shown as different from the type of reservoirs (static / running water, indoor or outdoor), feeding methods, and the species of grown shrimp. Features of the nutritional standards for freshwater and saltwater shrimps were analyzed. Nutrient requirements of shrimp have been changed through shrimp life-cycle. The shrimp life-cycle was shown.

World leaders-producers of compound mixed feeds for shrimps were shown. The analysis of pellet size and nutritional value of compound mixed feeds of crude protein content in prestart, starter, grower and finish periods of cultivation and in accordance with the system of cultivation and feeding shrimp (intensive, extensive, semi-intensive) is carried out. The requirements for the content of main minerals, vitamins and restrictions to the content of crude fiber are given. Traditional ingredients are described. Binders and preservatives, which are used for shrimp feeds, are shown and subscribed. In raw material the main problem is the need to ensure high protein content in the shrimp feed recipes. Because of many factors, fish meal quantity should be reduced in recipes. Because of its attractive amino acid content, availability and relatively affordable price, soybean meal and soy concentrates have received increasing attention as substitutes for marine animal meals.

The features of technological lines and processes of production of mixed feeds for shrimp are shown.

Ehe advantages and disadvantages of using the two most common processes of production of shrimp feeds (pelleting and extrusion), despite the relatively high cost extrusion, undoubtedly, is the main process of shrimp feed production.

At the same time, there are challenges, which need to be overcome by the industry for effective further development: to produce environmentally friendly feeds, to conduct further studies in order to clarify the required nutritional value of shrimp feed and add amino acids, feed enzymes, chemo-attractants, probiotics, and immunostimulants, to provide the necessary water stability of pellets, and to increase feed conversion rate, develop regional, national, or international guidelines and codes of practices for both feed manufacturing practices and feed management practices, reduce fish meal in shrimp feed recipes.

Despite the existence of problems, shrimp production is growing and the production of feed for their feeding has a great potential as an important source of animal protein in human nutrition.

Key words: compound feed for shrimp, feed manufacture technology for shrimp feed, requirements for shrimp feed.

Aquaculture has seen tremendous growth since 2011 , increasing market share by as much as $17 \%$ per year. The Food and Agriculture Organization of the United Nations (FAO) has released data indicating that trends in global consumption of farmed fish and shellfish exceeds that of beef on a weight basis [1]. Shrimp (or prawn) culture is widespread throughout the tropical world. It is in an industry set for a period of strongly growing demand, and is currently worth around US\$10 billion.

This article is intended to provide some detailed discussion, and information references where possible, on the perspectives and features of shrimp feed production.

Farming system and feeding strategies vary with shrimp size (larval, nursery, juvenile, adult), species and countries. Framing and feeding strategies used by farmers include [2]:

- extensive outdoor farming system with no additional nutrient input through fertilization or feeding (L. vannamei, P. monodon, P. chinensis, P. indicus.).

- extensive tidal/ running water outdoor farming system with fertilizer and / or complete / supplementary diet feeding (L.vannamei, P.monodon, P.chinensis, P.indicus)

- semi-intensive static / running water outdoor farming system with fertilizer and / or complete / supplementary diet feeding. (P.monodon, P.chinensis, L.vanname).

- intensive outdoor running / static water farming system with fertilizer and / or complete / supplementary diet feeding (P. monodon, L. vanname, F. dorarum, 
P.aztecus, F. merguensis).

- intensive indoor farming system with fertilizer and / or complete / supplementary diet feeding (P. monodon, L.vanname, P.indicus, P.esculentus).

Production cost depends on farming system and vary from 1-2 US dollar per kilogram of live shrimp to 5 US dollar [2] with feed conversation range from $0,9 \mathrm{~kg} / \mathrm{kg}$ to $3,0 \mathrm{~kg} / \mathrm{kg}$. While some 20 species are cultured in various parts of the world, the majority of production is based on six species (Figure 1) [3]. For the eastern hemisphere, the fast growing giant tiger shrimp Penaeus monodon is the most important, while in the western hemisphere, the white shrimp Litopenaeus vannamei is the leading production species. Feed most often represents the greatest percentage of the total cost of raising fish and shrimp. Therefore, correct requirements are necessary for feed production.

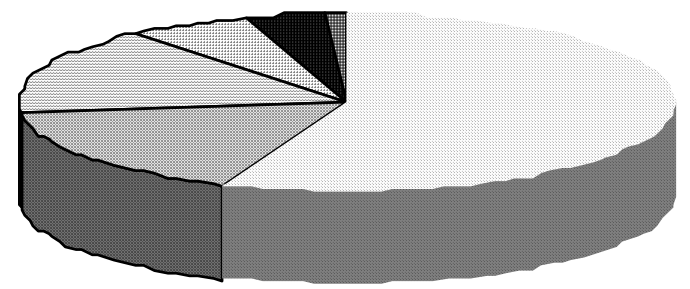
P. monodon
P. in dicus/ P. Merguen sis
$\square$ L. vannamei
P. chinen sis
P. stylirost ris
P. japonicus
Figure 1. Relative importance of shrimp species to global aquaculture production. Source Rosenberry, 1999 [3].

Shrimp have a complicated life cycle (Figure 2, [4]). Eggs from the female are broadcast into the environment. Hatching from the egg, the larvae pass through three distinct stages, nauplius, zoea and mysis, before assuming the distinctive adult morphology as post-larval or juvenile shrimp.

Formulated diets are available for post-larval and juvenile stages, enabling the farmer to rear the shrimp to maturity. Diets for broodstock shrimp typically include fresh or frozen supplements to the formulated diets. The bulk of feed used in the shrimp industry is the formulated feed used in the growout of juveniles to market size. These feeds for growout of shrimp typically contain high levels of protein. Using sources such as high quality fish, shrimp and squid meal, protein levels in the feed range from $30 \%$ to $50 \%$, depending on the shrimp species and culture strategy (Table 1). Lower levels of protein are used when shrimp are reared under extensive conditions.

The factors which determine the quality of a feed are its nutrient profile, anti-nutrient status, particle size, texture, stability of nutrients, attractability, digestibility, anabolic efficiency and shelf-life.

Nutrients essential to fish are the same as those required by most other animals. These include water, proteins (amino acids), lipids (fats, oils, fatty acids), carbohydrates (sugars, starch), vitamins and minerals.
Proteins and Amino Acids. Fish meal, soybean meal, grain by-products, skim milk powder, legumes, and wheat gluten are excellent sources of protein. Additionally, the building blocks of proteins (free amino acids) such as lysine and methionine are commercially available to supplement the diet. One of the most important issue in shrimp feed production is alternatives of animal protein sources. Several factors have stimulated efforts to find alternatives for marine protein sources in manufactured shrimp feeds. Certainly, price is the key reason to look for replacement. The supply and price of high quality fish meal, as well as shrimp and squid meals, fluctuate dramatically from year to year. There is also a general concern of the potential negative impact that fish meal production might have on natural fisheries $[5,11]$. Because of its attractive amino acid content, availability and relatively affordable price, soybean meal and soy concentrates have received increasing attention as substitutes for marine animal meals.

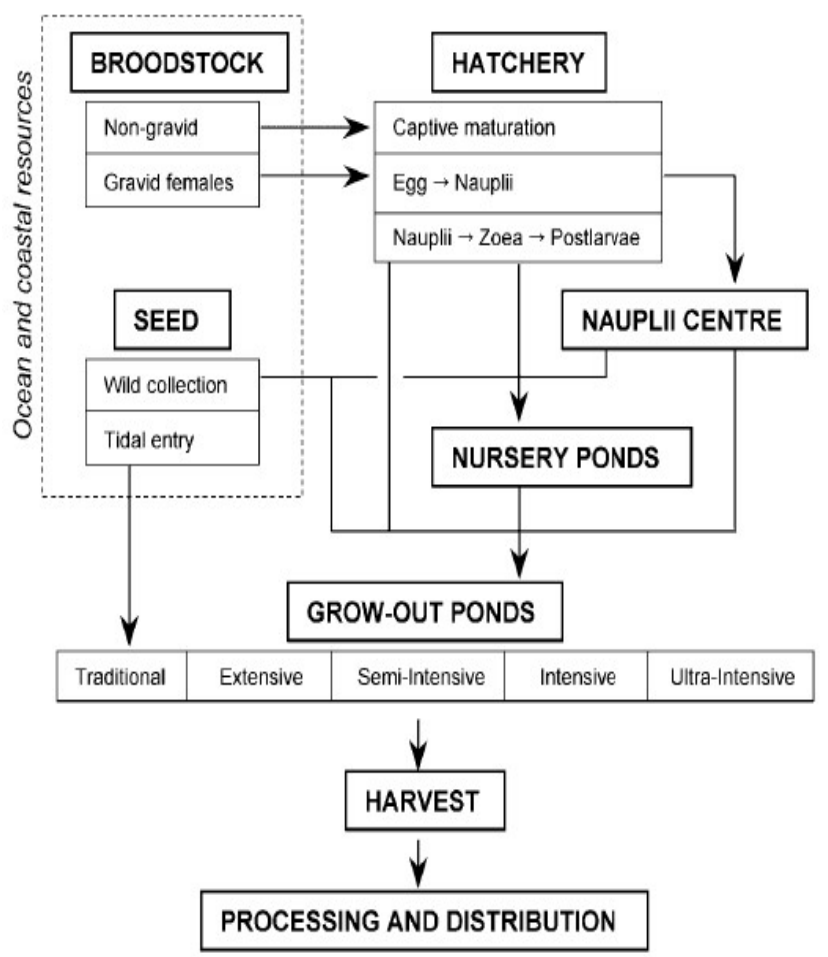

Figure 2. Production cycle for the cultured organism in industrial shrimp aquaculture. Adapted from Fast and Lester (1992) [4].

Table 1 Protein level in practical shrimp feed

\begin{tabular}{||c||c||}
\hline Cultural system & Crude protein \\
\hline \hline \multirow{2}{*}{ Extensive } & 23 \\
& 25 \\
\hline \hline \multirow{3}{*}{ Semi-intensive } & 30 \\
& 35 \\
& 40 \\
\hline \hline \multirow{2}{*}{ Intensive } & 40 \\
& 45 \\
\hline
\end{tabular}

Lipids. Oils from marine fish, such as menhaden, and vegetable oils from canola, sunflower, and lin- 
seed, are common sources of lipids in shrimp feeds. Important topic is ensuring necessary $\mathrm{w}-3$ : w- 6 relation.

Carbohydrates. Cooked carbohydrates, from flours of corn, wheat and other cereals, are relatively inexpensive sources of energy that may spare protein (which is more expensive) from being used as an energy source.

Vitamins and Minerals. The variety and amount of vitamins and minerals are so complex that they are usually prepared synthetically and are available commercially as a balanced and pre-measured mixture known as a vitamin or mineral premix. This premix is added to the diet in amounts to ensure that adequate levels of vitamins and minerals are supplied to meet dietary requirements.

Binding Agents. Another important ingredient in shrimp diets is a binding agent to provide stability to the pellet and reduce leaching of nutrients into the water. Carbohydrates (starch, cellulose, pectin) and various other polysaccharides, such as extracts or derivatives from animals (gelatin), plants (locust bean), and seaweeds (agar and other alginates) are also popular binding agents.

Preservatives. Preservatives, such as antimicrobials and antioxidants, are often added to extend the shelf-life of shrimp diets and reduce the rancidity of the fats. Vitamin $\mathrm{E}$ is an effective, but expensive, antioxidant that can be used in laboratory prepared formulations. Commonly available commercial antioxidants are butylated hydroxyanisole (BHA), or butylated hydroxytoluene (BHT), and ethoxyquin. BHA and BHT are added at $0.005 \%$ of dry weight of the diet or no more than $0.02 \%$ of the fat content in the diet, while ethoxyquin is added at $150 \mathrm{mg} / \mathrm{kg}$ of the diet. Sodium and potassium salts of propionic, benzoic or sorbic acids, are commonly available antimicrobials added at less than $0.1 \%$ in the manufacture of shrimp feeds.

Minerals are inorganic components of the feed, which are components of hard and soft tissues, cofactors and/or activators of enzymes, also they have function in acid - base balance in production of membrane potentials and osmoregulation [6]. Recommended mineral levels in commercial shrimp feeds are shown in the table 2.

Table 2 Recommended mineral levels in commercial shrimp feeds

\begin{tabular}{||l||c||}
\hline \multicolumn{1}{|c||}{ Mineral } & Quantity per kg of feed \\
\hline \hline Calcium, maximum & $2,3 \%$ \\
\hline \hline Phosphorus, available & $0,8 \%$ \\
\hline \hline Magnesium & $0,2 \%$ \\
\hline \hline Potassium & $0,9 \%$ \\
\hline \hline Iron maximum & $200 \mathrm{mg}$ \\
\hline \hline Copper & $35 \mathrm{mg}$ \\
\hline \hline Zinc & $150 \mathrm{mg}$ \\
\hline \hline Manganese & $20 \mathrm{mg}$ \\
\hline \hline Selenium & $1 \mathrm{mg}$ \\
\hline \hline Cobalt & $0,05 \mathrm{mg}$ \\
\hline \hline
\end{tabular}

Physical properties of shrimp feed depend on shrimp feeding habits. For slow-feeding species such as shrimp good pellet stability is required. Also shrimp prefer sinking pellets (density greater than that of water, $\left.1 \mathrm{~g} / \mathrm{cm}^{3}\right)$.

The feed production involves grinding of raw materials (by hammer mill and micropulverizer, particle size up to 300 micron), mixing, steam condition, pelleting (extrusion), drying (to moisture below 10\%) for good shelf-life of feed.

Pelleting and extrusion are two most popular processes which are used for shrimp feed production. Both of them have pros and cons [7, 10]. The most important advantages of extrusion cooking of shrimp feed are: reduced feed ingredient costs, improved feed water stability, reduced nutrient leaching, improved nutrient digestibility, increased oil and energy addition, higher starch gelatinization, increased feed efficiency, increased potential shrimp growth and profit per unit of feed intake. Also extrusion causes potential savings in recipe costs (extruded recipes reported to have $\$ 20-\$ 100 /$ ton potential savings over pelleted recipes, extrusion process allows reduction or elimination of special binders and extrusion process can use less expensive starch sources. However, extrusion has higher operating costs (operating costs for extrusion typically reported to be $\$ 20-25 /$ ton higher than for pelleting). are $[8,12]$ :

The most current challenges of shrimp farming

1. Production eco-friendly shrimp feed (minimum faecal and metabolic wastes).

2. The dietary nutrient requirements of shrimp under practical farming conditions, particularly in outdoor ponds, are not well understood. Aquafeeds and feeding strategies suited to the farming system need to be developed in order to reduce feed costs and avoid unnecessary nutrient input, feed wastage, and environmental pollution.

3. The potential value of feed additives such as free amino acids, feed enzymes, chemo-attractants and feeding stimulants, probiotics, and immunostimulants for farmed shrimp needs to be recognized, and practical application technologies for their successful incorporation in manufactured aquafeeds need to be developed.

4. Shrimp farmers may deficiency of understanding of the major nutritional role played by natural food organisms (including microorganisms) in the overall diet of shrimp raised under practical farming conditions.

5. There is an urgent need to maximize dietary nutrient utilization efficiency and minimize nutrient loss and feed wastage resulting from pellet disintegration, nutrient leaching, and/or overformulation.

6. The industry needs to recognize the increased dietary nutrient requirements of shrimp for the maintenance of optimum health and disease resistance under practical farming conditions.

7. The farmed shrimp industry needs to reduce its dependence on wild-caught seed and broodstock by developing improved processing and manufacturing techniques for the production of larval, nursery, and broodstock feeds.

8. Shrimp farmers need to maximize feed conversion efficiency and minimize feed losses and related 
deleterious environmental impacts by developing improved on-farm feed handling and management methods.

9. Aquaculture feed manufacturers and shrimp farmers must develop regional, national, or international guidelines and codes of practices for both feed manufacturing practices and feed management practices.

Table 3 Crude protein content of shrimp feed

\begin{tabular}{||c||c||c||c||c||}
\hline \hline \multirow{2}{|c||}{\begin{tabular}{c} 
Period $\begin{array}{c}\text { of } \\
\text { feeding }\end{array}$ \\
\cline { 2 - 5 }
\end{tabular}} & $\begin{array}{c}\text { Crude protein content in shrimp feed, \% } \\
\text { Ltd }\end{array}$ & $\begin{array}{c}\text { Hoc Po } \\
\text { Feeds } \\
\text { Corporation }\end{array}$ & $\begin{array}{c}\text { Ananda } \\
\text { Group }\end{array}$ \\
\hline \hline $\begin{array}{l}\text { Pre- } \\
\text { start }\end{array}$ & 41 & 36 & 40 & 38 \\
\hline \hline Start & 35 & 36 & 40 & 38 \\
\hline \hline Grower & 35 & 36 & 38 & 36 \\
\hline \hline Finisher & 35 & 34 & 38 & 36 \\
\hline
\end{tabular}

The biggest shrimp feed producers are: «Growel», Waterbase Ltd, Hoc Po Feeds Corporation, «Hocpo», Rangen, «Anand», «Nutrimo», «Skretting», «BioMar Group» etc. Crude protein content of shrimp feed depends on feeding period and differs from $34 \%$ to $42 \%$ (table 3 ), crude fat is $2 \ldots 3 \%$ and crude fiber content is not more than $3 \%$. Also there are different sizes of feed pellets for shrimp. It is $0,1 \ldots 0,3 \mathrm{~mm}$ for pre-start, $0,6 \ldots 1,0 \mathrm{~mm}$ for start shrimp, $1,0 \ldots 2,0 \mathrm{~mm}$ for grower, finisher feed $-2,3 \mathrm{~mm}$ and bigger.

\section{CONCLUSION}

Even through there are many challenges, shrimp feed production has great potential as important source of animal protein. The article shows farming system and feeding strategies of shrimp production. Feeds are major part of shrimp production cost. Ingredients which can be used for feed preparation were shown. Features of feed processes were discusses, as well as chemical composition of most popular shrimp feeds.

\section{REFERENCES}

1. Alltech. Global Feed Survey Summary. Alltech internal research report, 2013, - 8 p.

2. Tacon A.G.J. Dietary strategies for marine shrimp: review. Tacon A.G.J., Nates, S.F. \& McNeil. R. J. // In.: Gruz Suarez L.E., ricque Marie, Nietto Lopez, M.G.Vallarreal, D. Scholtz. Avances en nutricion Acuicola VII. Memorias del VII Simposium Internasional de Nutricion Acuicola, - 2004, p. 695-706.

3. Rosenberry R. World Shrimp Farming // Shrimp News International, -No.12., San Diego, USA, - 320p

4. Akiyama, D.M., Dominy, W.G., Lawrence, A.L. (1992). Penaeid shrimp nutrition. E.W. Fast, L.J. Lester, eds. Marine Shrimp Culture: Principles and Practices. Elsevier Science Publishers B.V., Amsterdam, The Netherlands.

5. Naylor, R.L., Goldburg, R.J., Primavera, J.H., Kautsky, N., Beveridge, M.C.M., Clay, J., Folke, C., Lubchenco, J., Mooney, H., Troell, M. (2000) Effect of aquaculture on world fish supplies. Nature (London) 405: 1017-1024.

6. Tim O'Keefe (2011). Nutrition and Feeds for Marine Shrimp. Tim O'Keefe (Aqua-Food Technologies, Inc.) and Mark Newman (M.N. Aqua Nutrition Consulting), ASA-IM SEA Technical Director (Aquaculture).

7. Riaz, M. N., Anjum, F. M., Khan, M. I. (2007). Latest trends in food processing using extrusion, technology PAK. J. FOOD SCI., 17(1), pp. 53-138

8. Albert G.J. Tacon. Global overview on the use of fish meal and fish oil in industrially compounded aquafeeds: Trends and future prospects. / Albert G.J. Tacon, Marc Metian // Aquaculture 285 (2008) 146-158.

9. David J. W. Moriarty Disease Control in Shrimp Aquaculture with Probiotic Bacteria, Microbial Biosystems: New Frontiers Proceedings of the 8th International Symposium on Microbial Ecology // Atlantic Canada Society for Microbial Ecology, Halifax. - Canada.-1999. - P.23-29.

10. Joseph P. Kearns Presentation. Technological Advances in the Manufacture of Feeds for Marine Farmed Shrimp: Pelleted versus Extruded Rations.

11. Joseph P. Kearns, Addison L. Lawrence. Extrusion of micro aquatic and shrimp feeds // AQUAFEED.- 2010.- №4. - C. 26.

12. Growth and feed utilization of the shrimp Farfantepenaeus paulensis fed diets containing different marine protein sources $/$ Ronaldo O. Ronaldo O., C. S. Zimmermann, R.C. Speck Ciência Rural.- Santa Maria, v.34, n.3.- 2004. -p. 891-896.

13. Tacon, A.G.J. Thematic Review of Feeds and Feed Management Practices in Shrimp Aquaculture. Report prepared under the World Bank, NACA, WWF and FAO Consortium Program on Shrimp Farming and the Environment // Work in Progress for Public Discussion. Published by the Consortium. - 2002. - $69 \mathrm{p}$.

\section{Л.В. ФІГУРСЬКА, канд. техн. наук, ст. викл., кафедра технології комбікормів та біопалива Одеська національна академія харчових технологій \\ ТЕНДЕНЦЇ̈ ТА ОСОБЛИВОСТІ ВИРОБНИЦТВА КОМБІКОРМІВ ДЛЯ КРЕВЕТОК}

\section{Анотація}

У статті зазначено, щьо аквакультура - ие сектор харчової промисловості, який інтенсивно зростає протягом останніх 25 років з щорічним приростом у 8,2\%. Однією з найбільш перспективних галузей аквакультури є розведення креветок. Витрати на комбікорми складають до 80 \% від вартості розведення креветок, тому забезпечення галузі високоцінними комбікормами є важливим завданням комбікормової галузі. Теоретичне дослідження було присвячено проблемі виробництва комбікормів для креветок. Показані існуючі системи розведення креветок, які відрізняються від виду водойм (з проточною чи ні водою, закриті чи під відкритим небом), способу годівлі, та виду вирощуваних креветок. Проаналізовано особливості стандартів годівлі для прісноводних і морських креветок. Поживна иінність комбікормів для креветок залежить від етапу життєвого ичклу ракоподібних. Наведені світові лідери-виробники комбікормів для креветок, проведено аналіз розмірів гранул та поживної иінності комбікормів за вмістом сирого протейну у престартовий, стартовий, ростовий та фінішний періоди вирощування і відповідно до системи вирощування, і типу годівлі креветки (інтенсивний, екстенсивний, напівінтенсивний). Наведено вимоги до вмісту основних мінеральних речовин, вітамінів та обмеження до вмісту сирої клітковини. Зазначено основну сировину, яку традиційно використовують при виробництві даних комбікормів, наведено зв'язуючи речовини та консерванти, які використовують при створенні рецептів кормів для креветок. Головною сировинною проблемою залишається необхідність забезпечити високий вміст білку у рецептах. Із за багатьох чинників кількість рибної муки повинна бути зменшена в рецептах комбікормів. Завдяки своїй привабливості амінокислотним складом, 
поширенням і порівняно доступною иіною, соєвій муці та соєвим концентратам приділяють все більшу увагу як замінникам морських тваринних продуктів.

Показано особливості ліній та технологічних процесів виробництва комбікормів для креветок. Наведено переваги і недоліки використання двох найпоширеніших процесів виробництва комбікормів для креветок - гранулювання та екструдування, екструдування незважаючи на порівняно вищу вартість як капітальну, так і експлуатації, безсумнівно, саме екструзія є основним прочесом виробництва комбікормів.

Разом з тим відзначено виклики, які потрібно подолати галузі для ефективного подальшого розвитку: виробляти екологічно чисті корми, зменшувати кількість рибної муки у рецептах, продовжувати подальші дослідження з уточнення необхідної поживності комбікормів для креветок та використання різних амінокислот, кормових ферментів, хемоаттрактантів, пробіотиків та імуностимуляторів.

забезпечувати необхідну водостійкість гранул, підвищувати конверсію корму, створювати регіональні, національні або міжнародні рекомендації та методичні вказівки виробництва та використання комбікормів для креветок.

Незважаючи на існування проблем, вирощування креветок $і$ виробництво комбікормів для їх годівлі мають великий потенціал розвитку для забезпечення тваринного білка у харчуванні людей.

Ключові слова: комбікорми для креветок, технологія виробництва кормів для корму для креветок, вимоги до корму для креветок.

\section{ЛITEРАТУРА}

1. Alltech. Global Feed Survey Summary. Alltech internal research report, 2013, - 8 p.

2. Tacon A.G.J. Dietary strategies for marine shrimp: review. Tacon A.G.J., Nates, S.F. \& McNeil. R. J. // In.: Gruz Suarez L.E., ricque Marie, Nietto Lopez, M.G.Vallarreal, D. Scholtz. Avances en nutricion Acuicola VII. Memorias del VII Simposium Internasional de Nutricion Acuicola, - 2004, p. 695-706.

3. Rosenberry R. World Shrimp Farming // Shrimp News International, -No.12., San Diego, USA, - 320p.

4. Akiyama, D.M., Dominy, W.G., Lawrence, A.L. (1992). Penaeid shrimp nutrition. E.W. Fast, L.J. Lester, eds. Marine Shrimp Culture: Principles and Practices. Elsevier Science Publishers B.V., Amsterdam, The Netherlands.

5. Naylor, R.L., Goldburg, R.J., Primavera, J.H., Kautsky, N., Beveridge, M.C.M., Clay, J., Folke, C., Lubchenco, J., Mooney, H., Troell, M. (2000) Effect of aquaculture on world fish supplies. Nature (London) 405: 1017-1024.

6. Tim O'Keefe (2011). Nutrition and Feeds for Marine Shrimp. Tim O'Keefe (Aqua-Food Technologies, Inc.) and Mark Newman (M.N. Aqua Nutrition Consulting), ASA-IM SEA Technical Director (Aquaculture).

7. Riaz, M. N., Anjum, F. M., Khan, M. I. (2007). Latest trends in food processing using extrusion, technology PAK. J. FOOD SCI., 17(1), pp. 53-138.

8. Albert G.J. Tacon. Global overview on the use of fish meal and fish oil in industrially compounded aquafeeds: Trends and future prospects. / Albert G.J. Tacon, Marc Metian // Aquaculture 285 (2008) 146-158.

9. David J. W. Moriarty Disease Control in Shrimp Aquaculture with Probiotic Bacteria, Microbial Biosystems: New Frontiers Proceedings of the 8th International Symposium on Microbial Ecology // Atlantic Canada Society for Microbial Ecology, Halifax. - Canada.-1999. -P.23-29.

10. Joseph P. Kearns, Addison L. Lawrence. Extrusion of micro aquatic and shrimp feeds // AQUAFEED.- 2010.- №4. - C. 26.

11. Growth and feed utilization of the shrimp Farfantepenaeus paulensis fed diets containing different marine protein sources $/$ Ronaldo O. Ronaldo O., C. S. Zimmermann, R.C. Speck Ciência Rural.- Santa Maria, v.34, n.3.- 2004. -p. 891-896.

12. Tacon, A.G.J. Thematic Review of Feeds and Feed Management Practices in Shrimp Aquaculture. Report prepared under the World Bank, NACA, WWF and FAO Consortium Program on Shrimp Farming and the Environment // Work in Progress for Public Discussion. Published by the Consortium. - 2002. - 69 p.

Надійшла 27.02.2018. До друку 10.03.2018 Адреса для переписки: вул. Канатна, 112, м. Одеса, 65039

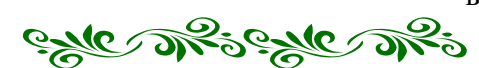

\section{РЕЗУЛЬТАТИ ЛУЩЕННЯ-ШЛТФУВАННЯ ЯЧМЕНЮ В АБРАЗИВНО-АИСКОВІЙ МАШИНІ А1-ЗШН-З}

\footnotetext{
Анотація

На підприємствах по виробнищтву крупів широко застосовуються лущильно-иліфувальні машини типу А1-3ШН-3 та їх аналоги, щңо відрізняються розмірами робочої зони та відповідно продуктивністю. Основними недоліками ицих машин $\epsilon$ низька ефективність лущення-иліфування та високі питомі енерговитрати. Забезпечення якісної обробки поверхні крупів досягається багатократними послідовними пропусками крізь однотипні машині. Підвищення ефективності використання машин можливо на основі закономірностей, отриманих під час випробувань на виробництві.

В статті наведені результати виробничих випробувань лущчильно-иліфувальної машини типу А1-3ШН-3 при переробиі ячменю різної вологості. В першій серії дослідів використовували ячмінь вологістю $W=13,8 \%$, в другій $W=10,1 \%, 6$

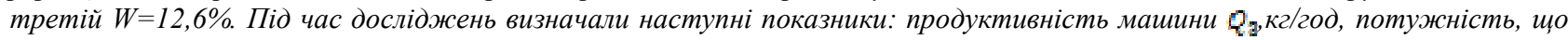

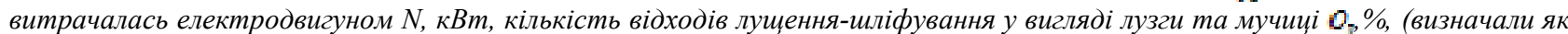
різниџю між масами ячменю до обробки і після, поділену на масу до обробки), коефіцієнт відвіювання лузги і мучиці в машині К, \% (відношення відходів лущення-шліфування виділених системою аспірації в машині до повної кількості утворених відходів лущення-иліфування). Контролювали кількість дрібки Др,\%, що утворюється у машині. Розраховували питому енергоємність утворення відходів лущення-шліфування як відношення потужності, щя витрачається електродвигуном $N$,
} 